\title{
RECENT (AND FUTURE) DEVELOPMENTS OF EU COMPETITION LAW: MATTERS OF POLICY AND OF MEMBER STATES COOPERATION
}

\author{
Silvia Marino, PhD, Associate Professor \\ Università degli Studi dell'Insubria \\ Via Sant'Abbondio 12, 22100 Como, Italy \\ silvia.marino@uninsubria.it
}

\begin{abstract}
EU Competition law has recently incurred main procedural reforms. Their basis must be found in Regulation 1/2003, decentralizing the control on the application of Articles 101 and 102 TFEU, thus emphasising the role of National Competition Authorities and Courts. This system has proved to be far from complete and perfect, as the first part of this article aims at demonstrating. A new political wave has enabled to strengthen the enforcement of EU Competition Law under two strands: the private and the public enforcement.

Directive 2014/104 harmonises parts of the national (civil) procedural law regarding damages actions. Powers and duties of National Courts are its focus. Its main features are recalled within this contribution. The long-awaited Directive 2019/1 aims at further reinforcing the role of NCAs, establishing a very detailed piece of legislation, whose main elements are briefly examined here. Since the two acts have been adopted in a quite short period of time, their coordination is analysed too.
\end{abstract}

This exam can lead us to offer some remarks on the perspective role of EU Competition Law, both from the Member States perspective and the needs for reform, and the new Commission's approach to the consistent application of the new legislation.

Keywords: EU Competition Law, Private Enforcement, Public Enforcement, Decentralisation, National Competition Authorities, Member States implementation 


\section{INTRODUCTION: THE DECENTRALISATION OF THE ENFORCEMENT OF EU COMPETITION LAW}

The enforcement of EU Competition Law has incurred deep reforms in recent decades. The (r)evolution started with the adoption of Regulation $1 / 2003^{1}$ on the implementation of Articles 81 and 82 TEC (Nice) (hereafter: Regulation) and the straightforward case law of the Court of Justice of the European Union (hereafter: CJEU) on damages actions for infringement of the same Treaty's rules. This development seems to have reached a completion with the enactment of Directive 2014/104 on damages actions ${ }^{2}$ (hereafter: Directive 104) and of Directive 2019/1 (hereafter: Directive 1) on the empowerment of National Competition Authorities $^{3}$ (hereafter: NCA(s)).

Both Directives were much awaited in order to secure legal certainty to private parties, from both the victims' and the infringers' perspective, and a level playing field where EU Competition Law is uniformly applied within all Member States.

Indeed, Directive 1 constitutes a sort of follow-up to the Regulation. This transformed the previous system of enforcement and the control of the respect of EU Competition Law, from both the political and technical perspectives, decentralising the public enforcement of EU Competition Law through the institution of NCAs.

This notwithstanding, the Regulation devoted only a few provisions to NCAs. Among these, Article 35 laid down a duty to Member States to establish a NCA, with administrative or jurisdictional nature, responsible for the application of Competition Law. The Regulation determined the NCAs main competences: Article 3 conferred the power to apply current Article 101 and 102 TFEU, along with national legislation on cartels and abuses of dominant position, while Article 5 granted the competence to apply EU Competition Law autonomously. For this purpose, the provision listed a set of powers for NCAs acting on their own initiative or on a complaint. In particular, they could issue five kind of decisions: the cessation of the infringement; interim measures; the acceptance of commitments; the imposition of fines or other penalties; the closing up of the investigation due

Council Regulation (EC) No 1/2003 of 16 December 2002 on the implementation of the rules on competition laid down in Articles 81 and 82 of the Treaty [2003] OJ L 1/1

2 Directive 2014/104/EU of the European Parliament and of the Council of 26 November 2014 on certain rules governing actions for damages under national law for infringements of the competition law provisions of the Member States and of the European Union [2014] OJ L 349/1

3 Directive (EU) 2019/1 of the European Parliament and of the Council of 11 December 2018 to empower the competition authorities of the Member States to be more effective enforcers and to ensure the proper functioning of the internal market [2019] OJ L 11/3 
to lack of interest; no grounds for action on their part, including orders requiring that an infringement be brought to an end, and imposing fines ${ }^{4}$. NCAs margin of appreciation and powers were limited only by Article 16(2), since they could not adopt decisions which would run counter a Commission's decision issued on the same case.

Article 15, although positioned within the Chapter on Cooperation, conferred the NCAs the competence to act as amicus curiae within national proceedings, where issues on the application of EU Competition Law were dealt with ${ }^{5}$. Article 11, 12 and 13 established some main rules on the functioning of the European Competition Network (hereafter: ECN), with regard to cooperation and information exchange between the Commission and NCAs. Article 22 finally laid a duty of cooperation among Authorities ${ }^{6}$, in that each NCA had to perform the investigations provided for by its national legislation when requested to do so by the Commission or another NCA.

Some regulatory lacks emerged immediately after the first practice of the Regulation. These depended on its general approach, which was evident for example from the black letter of Article 22, in that it implicitly referred back to national law for the constitution and the correct functioning of NCAs. The efficiency of the NCAs was entrusted with Member States procedural autonomy, to be balanced with the principle of effectiveness of the application of EU Competition Law recalled in Article 357. Furthermore, the mere listing of the decisions to be taken by the NCAs left Member States free to rule their internal procedures, the sanctions and their calculation. Except from the quite general Article 5, whose content differs from the powers vested with the Commission, the Regulation did

4 Pace, L.F., La politica di decentramento del diritto antitrust CE come principio organizzatore del regolamento 1/2003: luci e ombre del nuovo regolamento di applicazione degli artt. 81 e $81 \mathrm{CE}$, Rivista Italiana di Diritto Pubblico Comunitario, vol. 14, no. 1, 2004, pp. 147-197, at 157

5 As the CJEU, Case C-429/07, Inspecteur van de Belastingdienst v X BV [2009] ECR I-04833 made it clear, this means that the main object of the proceedings might be different from the application of EU Competition Law. It is enough that the nature of the sanctions applied by the Commission (and by the NCA) were under discussion, in the proceedings filed after the ascertainment of the violation of Article 101 TFEU

6 The term "Authorities" designates jointly the Commission and the NCAs

7 Therefore, a system that does not grant standing to the NCA in judicial proceedings brought against its decisions is not effective, because only the claimant would be enabled to submit evidence and remarks suitable to contribute to the final judgment (Case C-439/08, VEBIC, [2010] ECR I-12471: Frese, M.J., Case C-439/08, Vlaamse federatie van verenigingen van Brood- en Banketbakkers, Ijsbereiders en Chocoladebewerkers (VEBIC), Judgment of the European Court of Justice (Grand Chamber) of 7 December 2010, Common Market Law Review, vol. 48, no. 3, 2011, pp. 893-906; Petit, N., The Judgment of the European Court of Justice in VEBIC: Filling a Gap in Regulation 1/2003, Journal of European Competition Law \& Practice, vol. 2, no. 4, 2011, pp. 340-344 
not provide for either common neither harmonised investigative, inspection and sanctioning powers in favour of the NCAs.

EU Commission noted that this autonomy has been exercised differently by Member States ${ }^{8}$, so that there were different models in the NCAs structures and consequently functions and powers 9 . These divergences risked undermining the correct application of EU Competition Law, since decentralisation could be effective insofar as NCAs exercise the same powers with the same specialised competences.

Commission Junker had put Competition as main priority with its activity and the prevailing political view has thus been in the sense that a reform of public enforcement was needed. Therefore, it has been possible to approve Directive 1 shortly after the submission of the Commission's proposal in March $2017^{10}$, without profound amendments. It consists in 77 recitals, 37 Articles and one Commission's declaration. Member States must implement it before $4^{\text {th }}$ February 2021, and notify the transpositions measures to the Commission (Article 34(1)).

\section{THE STRENGTHENING OF PUBLIC ENFORCEMENT: THE DIRECTIVE ON THE EMPOWERMENT OF THE COMPETITION AUTHORITIES}

Directive 1 focuses on public enforcement through the empowerment of NCAs for the better application of EU Competition Law. From its adoption, it is also

8 Commission Staff Working Document. Enhancing competition enforcement by the Member States' competition authorities: institutional and procedural issues, SWD(2014) 231/2. Accompanying the document Communication from the Commission to the European Parliament and the Council. Ten Years of Antitrust Enforcement under Regulation 1/2003: Achievements and Future Perspectives $\{\mathrm{COM}(2014)$ 453\} \{SWD(2014) 230\}

9 For a comparative perspective: Pera, A.; Falce, V., The Modernisation of EC Competition Law and the Role of National Competition Authorities - Revolution or Evolution?, Diritto dell'Unione europea, vol. 8, no. 2-3, 2003, pp. 433-454; Reichelt, D., To what extent does the co-operation within the European Competition Network protect the right of undertakings?, Common Market Law Review, vol. 42, no. 3, 2005, pp. 745-782; Tesauro, G., The evolution of European competition law and the Italian Autorità Garante della Concorrenza e del Mercato, in: H. Ullrich (ed.), The Evolution of European Competition Law: Whose Regulation, Which Competition?, Cheltenham, 2006, pp. 71-83; Rusu, C.S., The Commission Communication on Ten Years of Antitrust Enforcement Under Regulation 1/003 - Prospective Priorities and Challenges, in: Almăşan A.; Whelan P. (eds.), The Consistent Application of EU Competition Law. Substantive and Procedural Challenges, Cham, 2017, p. 32; Melloni, M.; The European Competition Network (ECN) and its First 11 Years of Life: Balances and Challenges, in: Benacchio G.A.; Carpagnano M. (eds.) L'applicazione delle regole di concorrenza in Italia e nell'Unione europea, Napoli, 2015, p. 47; Malinauskaite J., Harmonisation of EU Competition law Enforcement, Springer, Cham, 2020

10 Proposal for a Directive of the European Parliament and of the Council to empower the competition authorities of the Member States to be more effective enforcers and to ensure the proper functioning of the internal market, COM/2017/0142 final - 2017/063 (COD), 22 March 2017 
known as Directive $\mathrm{ECN}+{ }^{11}$. Due to its novelty, we provide a short glance at its most meaningful provisions.

\subsection{Independence and resources}

Chapter III is devoted to independence and resources. It is applicable to NCAs with administrative nature, because independence should be a connatural requisite to jurisdictional bodies ${ }^{12}$, and the EU cannot influence financial and economic resources of the Courts, which is a matter of Member States' exclusive competence. Granting full independence to administrative bodies is not an easy task and the CJEU has already intervened in cases related to bodies whose institution is requested by EU Law. In si.mobil ${ }^{13}$ the Tribunal verified only the functional independence of the Slovenian NCA, that must be established by the law and granted with the powers conferred to the body. The analysis is therefore quite brief. The two cases related to the Austrian and the Hungarian supervisory authorises for the protection of personal data, to be established pursuant to Article 28 of Directive $95 / 46^{14}$, rise more sensitive issues. Functional autonomy is deemed not to be satisfactory, in that the independence of their key staffs shall be assured, too. Consequently, the appointment and the suspension of the Authorities boards shall be consistent with exigence of independence ${ }^{15}$.

Due to the difficulties to balance the duty to establish these bodies under EU Law, on one side, and to regulate their institution and functioning according to the principle of Member States procedural autonomy, on the other side, the length of Article 4 is not surprising. This provision affects various aspects related to the creation and the functioning of NCAs, such as the selection and the appointment of the members of the board; independence's duties from political interferences laid down on persons responsible to issue some decisions within their powers; a cooling off period.

11 See on EU Commission website: [https://ec.europa.eu/competition/antitrust/nca.html], Accessed 15 April 2020

12 Case C-286/12, Commission v. Hungary [2012] ECLI:EU:C:2012:687; Case C-64/16, Associação Sindical dos Juízes Portugueses [2018] ECLI:EU:C:2018:117; Case C-619/18, Commission v. Poland [2019] ECLI:EU:C:2019:531

13 Case T-201/11, si.mobil [2014] ECLI:EU:T:2014:1096

14 Directive 95/46/EC of the European Parliament and of the Council of 24 October 1995 on the protection of individuals with regard to the processing of personal data and on the free movement of such data [1995] OJ L 281/31

15 Case C-614/10, Commission v. Austria [2012] ECLI:EU:C:2012:631; Case C-288/12, Commission v. Hungary [2014] ECLI:EU:C:2014:237 
Furthermore, para. 5 establishes the power for NCAs to determine priorities in the implementation of their competences, that might lead to the dismissal of cases that do not appear particularly relevant or of manifestly unfounded complaints ${ }^{16}$.

The condition of adequate resources is functional to the independence (Article 5). Indeed, NCAs must not depend economically or financially on any other national body of any kind, that would at the very end be tantamount to a controller of the NCA. In Commission v. Austria, above, the Court criticizes the fact that the staff of the supervisory authority is composed by officials of the Federal Chancellery, that makes available the necessary equipment. This organisation risks creating a State influence on the body's work. That does not mean that the NCA must have an autonomous budget, but the availability of resources must not affect the organic independence. Accordingly, Article 5 of Directive 1 establishes that NCAs must be autonomous in the spending of the allocated budget.

\subsection{NCAs powers}

Once an independent NCA is established, Directive 1 confers it powers and competences. Article 5(2) recalls the minimum powers, whose conferral should be already clear from the Regulation, such as: to conduct investigations with a view to applying Articles 101 and 102 TFEU; to issue decisions based on Article 5 of Regulation; to cooperate in the ECN. NCAs shall also have consultative powers in favour of public institutions and bodies, but the provision leaves the advisory competence under national legislation.

The new powers are listed in Articles 6-9, and are both investigative and decisional. Their formulation recalls Articles 17-21 of the Regulation, that grant similar powers to the Commission. It emerges immediately that one of the targets of Directive 1 is the uniformity of powers within Authorities, so that NCAs with administrative nature shall benefit from the same competences and powers of the Commission. The positive practice of the Institution in the detection and the sanction of antitrust infringements leads to an extension of this model to other Authorities responsible for the application of the same Treaty rules ${ }^{17}$.

Directive 1 impacts on the decisional powers of NCAs. Articles 10-12 are applicable to bodies with jurisdictional nature, too, since the specification of the

16 In Case T-24/90, Automec [1992] ECR II-2223, para. 77 the Tribunal has expressed favour towards the Commission's power to set priorities, it being functional to the rational use of its resources

17 Rusu, C.S., Case Comment: Workload Division after the Si.mobil and easyjet Rulings of the General Court, The Competition Law Review, vol. 11, no. 1, 2015, pp. 163-172 notes that NCAs are the bodies with the best capacity to apply Competition Law and shall not be a mere extension of the Commission 
powers already granted by the Regulation do not jeopardise the judiciary, rather it reinforces it.

For these powers, too, the model is represented by Commission, in that Articles 10-12 retrace Articles 7-9 of the Regulation. Yet, there are some main differences between the two sets of provisions.

Directive 1 does not specify that structural remedies shall be considered more burdensome with respect to behavioural remedies (Article 7(1) of the Regulations). However, Article 10(1) of the Directive recalls the principle of proportionality, whom Article 7(1) can be a specification, and thus the same balance shall be applicable to NCAs, too.

Article 11 of Directive 1, devoted to interim measures, is much more precise than parallel Article 8 of the Regulation and to Article 10 of the Directive's Commission Proposal. The main divergence depends on the mention of the principle of proportionality as a limit both to the content and to the duration of the measure. This difference in the formulation of Article 8 of the Regulation and Article 11 of Directive 1 does not seem particularly relevant for the practice. Indeed, Commission's power to issue interim measures was recognized and limited by the CJEU in the sense of balancing the interests at stake ${ }^{18}$. Therefore, the Commission's powers are not so broad as might seem from the formulation of Article 8 of the Regulation.

The last meaningful difference regards findings on inapplicability, that remain a Commission's exclusive competence. Nevertheless, Article 10(2) strengthens the cooperation, establishing that NCAs must communicate the Commission the closing of enforcement proceedings because there are no grounds to proceed. By that, the Commission is better informed of the proceeding undertaken by NCAs, in order to verify NCAs activities both for statistical purposes and for the new opening of enforcement proceedings in doubtful cases.

An accordance with the Commission's decisions appears suitable for the uniform application of EU Competition Law. This shall not depend on the authority investigating the case and issuing a decision. Therefore, if slight differences stem from the European or national, administrative or judicial nature of the authority, or from peculiarity of national jurisdiction, the output of the control procedure must not be divergent. The consequences risk being unforeseeable for undertakings and

18 Case 792/79, Camera Care [1980] ECR 119; Cases 228 e 229/82, Ford [1982] ECR 2849; Case T-184/01R, IMS Health Inc [2001] ECR II-3193 
associations of undertakings when operating in the market or even calculating the costs/benefits of the infringement(s).

The harmonisation of the sanctioning powers is based on the same uniformity purposes.

\subsection{Leniency programmes}

A lengthy part of Directive 1 is devoted to leniency programmes (Chapter VI). According to the Commission, these are the most efficient tools in order to have knowledge and to put an end to secret cartels ${ }^{19}$. Therefore, these means must be available to all NCAs. Since the 2006 Commission's Model Leniency Program, many Member States have introduced these programmes ${ }^{20}$, whose contents and procedures have been partly harmonising thanks to the cooperation within the $\mathrm{ECN}^{21}$. Thus, Directive 1 fills the remaining gaps and inconsistencies related to some specific aspects that emerged in the application of the leniency programmes. Chapter VI deals with the quality of the contribution offered by the whistle-blower, the favourable treatment to be granted, its relationship with the Authorities with which it has not filed a request of application, the possible benefits for the other involved undertakings' cooperation with the authority. These provisions are inspired by the 2012 ECN Model Leniency Programme, which has played a role as a guideline for NCAs, although it not being binding.

The setting of uniform conditions for the benefiting from the immunity or the reduction of the sanctions avoids the distortion of the potential "forum selection" of the whistle-blower, that might prefer to lodge an application to a NCA whose requisites are not rigorous. In this new uniform legal framework, rules on NCAs competence seem less needed, since the final decision should be the same, notwithstanding the seized NCA. The sole difference remains if the Commission is also seized with an application covering more than three Member States, because Article 22(3) of Directive 1 accords it a preference with an estoppel effect.

Directive 1 provides for a procedural harmonisation, too, having regard to the start of the proceedings and the coordination with Commission's activity. Nevertheless, pursuant to the principles of proportionality and of Member States procedural

19 The major part of Commission's decisions find their origins in a request for application of a leniency programme (Commission Staff Working Document. Ten Years of Antitrust Enforcement under Regulation 1/2003, cit., note 8, par. 217)

20 Melloni, op. cit., note 9 , p. 48

21 Chirițoiu, GB.M., Convergence Within the European Competition Network: Legislative Harmonization and Enforcement Priorities, in The Consistent Application, cit. note 9, p. 3 
autonomy ${ }^{22}$, Directive 1 accepts only some of the elements already stated in the Leniency Model Program, while Member States continue to be free to introduce a legislation perfectly corresponding to the Model.

\subsection{Directive 1 and national reforms}

The impact of Directive 1 on Member States depends strictly on the structure and the powers already conferred to each NCAs after the Regulation in every jurisdiction. A strong difference can be already established in States where NCA has a judicial nature, or where it is an administrative body. In the former, the most important part is that referring to sanctions, that is able to strengthen the available enforcement tools, thus modifying the current sanctioning powers of the judiciary within this specific competence. In the latter, Directive 1 can have a strong impact, so that Member States might need to reform radically the organisation, the functioning and the powers of their NCAs. Some studies have already been published ${ }^{23}$, showing the different impact of the Directive in various Member States.

The second meaningful remark relates to the precise formulation of most of the Directive's provisions. Therefore, a direct effect can be quite easily determined, especially with regard to the investigative and sanctioning powers and to the cooperation within the ECN. Hopefully, the detailed character of Directive 1 incentivises Member States to implement it correctly and on time, so as not to incur in infringement proceedings and especially into a legislation derived from the direct effect and not from although limited national regulatory choices.

\section{THE GROWTH OF PRIVATE ENFORCEMENT}

\subsection{The CJEU's case law}

In the same years of the decentralisation, private enforcement of EU Competition Law has started being a core issue in EU Competition Law. It finds out its roots with CJEU's case law. The judgments are well known and we only need to recall here their impact in the development of the application of EU Competition Law.

\footnotetext{
22 This is particularly relevant if the NCA has jurisdictional nature

23 Malinauskaite, op. cit., note 9, on Central and Eastern European Member States; Marino, S., Il rafforzamento dell'azione delle autorità nazionali garanti per la concorrenza: un nuovo impulso dall'Unione europea, Rivista italiana di diritto pubblico comunitario, vol. 29, no. 3-4, 2019, pp. 537-557 on Italian NCA
} 
Since the Courage case ${ }^{24}$ it is established case law that the victims of an anti-competitive behaviour can claim damages against the infringer(s), since current Article 101(1) TFEU has direct effect ${ }^{25}$. Further, the effective protection of competition in the internal market required the compensation of any damage incurred because of the infringement. Subsequent case law has clarified this principle. The CJEU had the opportunity to stress that anyone is entitled to a damages action, even if the claimant is a consumer (Manfredi case $^{26}$ ), or the Commission itself (Otis $\left.\operatorname{cas}^{27}\right)$, or a person suffering damages because of the "umbrella-pricing" effect (Kone case ${ }^{28}$ ). Recently this case law was further enriched in the sense that even public "persons who are not active as suppliers or customers on the market affected by a cartel, but who provide subsidies, in the form of promotional loans, to buyers of the products offered on that market" might have legal standing to sue the infringers ${ }^{29}$. Actually, there does not seem to be limitations on standing, provided that the other conditions for liability are met, i.e. the illegal conduct, the damage and the causality. Furthermore, the CJEU has set out some principles on the limitation periods, and on the quantification of the damages (Manfredi case). More recently, a meaningful case law is being formed as for the application of the rules on international jurisdiction and applicable law to cross borders claims on damages for infringement of EU Competition $\mathrm{Law}^{30}$. This is due to the strong success of private enforcement ${ }^{31}$ together with the lack of any specification on civil judicial rules within Directive 104.

The first case law referred to represents a set of basic general principles for damages claims, but did not affect directly national legislations. Indeed, failing any EU harmonisation, damages actions were subject to (procedural and substantive) national law(s), balanced with the principles of effectiveness and equivalence, and by the rules stated by the CJEU case law. Here again, the fragmentation of laws applicable to the same infringement or type of infringements risked undermining the uniform application of EU Competition Law and the rights of the victims.

\footnotetext{
24 Case C-453/99, Courage and Crehan [2001] ECR I-6297

25 Case 127/73 BRT [1974] ECR 313

26 Case C-295/04, Manfredi [2006] ECR I-6619

27 Case C-199/11, Otis [2012] ECLI:EU:C:2012:684

28 Case C-557/12, Kone AG and Others v ÖBB-Infrastruktur AG [2014] ECLI:EU:C:2014:1327

29 Case C-435/18, Otis [2019], ECLI:EU:C:2019:1069, para. 34

30 Case C-353/13, CDC [2015] ECLI:EU:C:2015:335; Case C-27/17, flyLAL [2018] ECLI:EU:C:2018:533; Case C-595/17, Apple [2018] ECLI:EU:C:2018:854; Case C-451/18, Tibor-Trans [2019] ECLI:EU:C:2019:635

31 Calvo Caravaca, A.L.; Carrascosa González J., El Derecho internacional privado de la Unión Europea frente a las acciones por daños anticompetitivos, Cuadernos de derecho transnacional, vol. 10, no. 2, 2018, pp. 7-178
} 
Thus, again the setting of Competition as a Commission's priority has led to a prevailing political approach ${ }^{32}$ in the sense of overcoming this situation through the adoption of a harmonising EU measure aimed at granting the same level playing field among Member States. The result of a long period of debates is Directive 104. The deadline for transposition was established on $27^{\text {th }}$ December 2016.

\subsection{An overview on the novelties of Directive 104 and on its impact within Member States}

Directive 104 harmonises only certain aspects of damages actions. Therefore, the principles of national procedural autonomy, of effectiveness and of equivalence are still good law for all the aspects not regulated, as recalled by Article 4.

The regulation aims at simplifying access to justice for the victims, in order to strengthen the role of private enforcement as an effective remedy against antitrust infringement. Thus, Directive 104 impacts on substantial parts of the proceedings on damages, contemplating rules on the right to full compensation; on the notion of victim and the legal standing; including the passing-on defence; the notion of defendant; the disclosure of evidence, with special rules if it is contained in the file of a NCA; the effects of NCAs decisions; and the causal link between the harmful event and the damage; consensual settlements and limitation periods.

In the perspective of the simplification, we only need to recall the (rebuttable) presumption that a cartel causes harm (Article 17(2)). Moreover, Article 14(2) eases the burden of proof of the passing-on, for the benefit of the indirect purchaser, with regard to the consumer, and proves its usefulness in follow-on actions ${ }^{33}$.

In the perspective of harmonisation, thus the creation of a level playing field, the most meaningful rules are those on limitations and on the cross-borders effects of NCAs decisions. Indeed, as for the former, the admissibility of an action does not depend on national statutes of limitations, so that a forum shopping based on limitations periods is practically impossible.

32 For an analysis of the backgrounds of the Directive see: Lianos, I.; David, P.; Nebbia, P., Damages Claims for the Infringment of EU Competition Law, Oxford University Press, Oxford, 2015, p. 33; Jones, A.; Sufrin, B., EU Competition Law. Text, Cases and Materials, Oxford University Press, Oxford, 2016, p. 1070; Wils, W.P.J., Private Enforcement of EU Antitrust Law and Its Relationship with Public Enforcement: Past, Present, Future, World Competition, vol. 40, no. 3, 2017, pp. 3-45

33 In these cases the claimant needs to prove a causal link leading from the infringer to the direct purchase and the purchase itself (which can be a bill or an invoice, for example). Indirect purchasers do not need to give evidence of the total or partial pass-on through the commercial chain that lead to them 
As for the latter, consideration at least as a prima facie evidence must be given to foreign NCAs decisions (Article 9(2)). Although this rule leaves a national margin of appreciation on the effect to be attributed to these decisions ${ }^{34}$, parties can be sure that they acquire some legal value in all Member States. For example, the defendant cannot completely rely on the absence of NCA's decisions in the judicial proceedings for damages, insofar as another NCA has established an infringement of EU Competition Law.

Due to Directive 104 impact on national procedure, national implementations have casted some difficulties, which varied depending on the sensitiveness of the Member State concerned ${ }^{35}$. Nevertheless, the short margin of appreciation left to Member States did not give the opportunity to express strongly diverging approaches in the implementation of the Directive, notwithstanding internal uncertainties. Most Member States implemented it on time, or with a short delay (as the case of Italy), with only few exceptions (as the case of Greece, transposing it in March 2018).

\section{THE INTERACTIONS BETWEEN PUBLIC AND PRIVATE ENFORCEMENT}

\subsection{The private enforcement perspective}

Both Directive 1 and Directive 104 accord short attention to the coordination between private and public enforcement.

Directive 104 states a few rules that might be considered as stating an implicit coordination. The former is Article 6, insofar as it establishes the conditions for NCAs documents disclosure. In that, it balances the needs of public enforcement, which may require confidentiality, with the purposes of private enforcement, which instead requires the availability of all the existing documents.

Article 6(6) provides for a "black list" of non-accessible documents, i.e. leniency statements and settlement submissions. In the balance between public and private enforcement, the former prevails, because leniency programmes have an extremely practical impact on the discovery of antitrust behaviours; at the same time, the

34 For example, the UK and Germany already granted legal binding effects to foreign NCAs' decisions, based on a high level of mutual trust between Member States. Italy has opted for a minimum implementation, so that the foreign decision may be presented as evidence, among other things, of the infringement against the infringer

35 For a comparative approach: Marino, S.; Biel, Ł.; Bajčić, M.; Sosoni V. (eds.), Language and Law, Springer, Cham, 2018, first part; Malinauskaite, op. cit., note 9 
whistle-blower is not in a worse position compared to the other cartelists/infringers in the private enforcement perspective.

In addition, Article 6(5) of Directive 104 provides for a "grey list", i.e. documents that can be disclosed after the termination of the NCA's proceedings. This rule aims at granting the effectiveness of the on-going public enforcement in relation with documents prepared specifically for the public enforcement proceedings, or drafted by the NCA, or finally settlement submissions that have been withdrawn. Again, the efficiency of private enforcement risks being set aside because of the impossibility to introduce good evidence of the infringement.

Article 6(4) lists a set of grounds to be taken in consideration to evaluate the proportionality of the disclosure order, which are strictly linked to public enforcement efficiency. The balance with private needs is to be found in the national Court's power to order the disclosure of the evidence to verify if it corresponds to the documents in the black or in the grey list.

Therefore, Directive 104 privileges the public enforcement, that shall continue without external interferences, even though these are constituted by damages actions arising from the same facts. Apparently, EU legislator seems to prefer followon claims, where the infringement can be considered as ascertained and documents are made more accessible.

Article 9, on the effects of national decisions, establishes the latter implicit means of coordination between public and private enforcement. The rule fills a gap left by Article 16 of the Regulation, and approximates national laws in a field where different solutions were adopted ${ }^{36}$. The decision of the NCA (of the State of the judge seized) and/or the judgment deciding on an appeal against it shall have a legal binding effect as regards the ascertainment of the infringement. No evidence to the contrary is admitted. Such solution calls upon legal certainty, so that a final administrative decision or judgment cannot be reopened again, at any time.

As mentioned the same legal effects cannot be granted to foreign NCAs' decisions. Automatic recognition of administrative decisions is not a goal already reached within Member States cooperation, and approximation of national legislations is not conceived. Nevertheless, EU Competition Law benefits from the cooperation system between the Commission and the NCAs, and among NCAs (Articles $11 \mathrm{ff}$. of the Regulation), which is reinforced under Directive 1. It cannot be argued that

36 Cortese, B., Defining the Role of Courts and Administrative Bodies in Private Enforcement in Europe: United in Diversity? in: Cortese, B. (ed.), EU Competition Law. Between Public and Private Enforcement, Alphen aan den Rijn, p. 145 
the foreign public enforcement systems are completely unknown and obscure. Therefore, the efficiency of public enforcement and the correct functioning of private enforcement require that public acts issued abroad were considered at least as prima facie evidence of the infringement.

These rules go in the same direction, in that the outputs of the public enforcement system must have an impact in the private enforcement, too.

\subsection{The public enforcement perspective}

Directive 1 devotes a few mentions to the coordination between the two enforcement systems.

Article 31 strengthens the protection of the whistle-blower already established by Directive 104 . Indeed, it prescribes limits to the use of information disclosed during NCAs proceedings. Only the parties to the administrative procedure can accede to the declarations released within a leniency programme, or a request for immunity or reduction of fine proceedings, and to the limited scope to exercise their rights of defence. This information can be used only within jurisdictional proceedings, insofar as they concern the allocation between cartel participants of a fine imposed jointly and severally on them by a NCA; or the review of a decision by which a NCA found an infringement of EU or national competition law. This rule appears consonant with Article 6(6) of Directive 104, in that the two rules offer a complete protection to the undertaking requesting the access to any of these favourable programmes: the information disclosed cannot be used in proceedings different from those concerning the infringements displayed, and the enterprise is not subject to sanctions for related facts and acts. Furthermore, the success of damages actions is scarce without this information.

Article 31(5) of Directive 1 is a parallel provision to Article 6(5) of Directive 1, so that the listed documents can be disclosed only after the conclusion of the NCA's ascertainment.

Notwithstanding the need for coordination, Directive 1 refers explicitly back to Directive 104 only twice. Article 14(2) repeats Article 18(3) of Directive 104, so that the NCA can take into consideration damages paid by the infringers for the calculation of the sanction within public enforcement. These rules risk having a limited scope, since they implicitly refer to stand-alone actions, more difficult to succeed for evidence reasons notwithstanding the simplification provided for by Directive 104. Their rationality is debatable, too, since private enforcement shall be a tool to strengthen EU Competition Law enforcement (recital 4 of Directive 104), to be added to and not to substitute public enforcement through sanctions' reductions. 
The second reference is contained in Article 23(5), on the interplay between applications for immunity from fines and sanctions on natural persons. It merely states that the protection of natural persons, as current and former directors, managers and other members of staff of applicants for immunity, shall not prejudice the right to compensation in favour of the victims. The rule appears misleading in such a context: damages actions shall be lodged against the infringer and not against natural persons representing it.

\subsection{A general perspective}

In the enforcement of EU Competition Law, two sets of remedies are established. Public enforcement shall aim at restoring competition in the internal market; private enforcement shall protect private interests through the availability of damages actions. Due to the different aims, these systems may coexist in perfect independence: on one side, private enforcement includes stand-alone actions not needing a previous Authority decision; on the other side, the ascertainment of an infringement by any Authority does not have as a consequence the lodging of followon damages actions. Nevertheless, the two prongs of the enforcement cannot be considered as perfectly separated. The outputs of public enforcement cannot but affect private enforcement; the grant of damages cannot but impact on private enforcement; the simultaneous pending of public and private antitrust enforcement proceedings shall be coordinated in order not to jeopardise the protection of the two protected interests - the market, the victims' rights. Separate legislations are therefore admissible stressing on the full independence of these remedies, but at the same time, they must be coherent and complete. The perceived lack of coordination risks undermining the full potential of the enforcement system, disregarding victims'/consumers' rights.

\section{SOME CONCLUDING REMARKS: PAST AND FUTURE OF THE ENFORCEMENT OF EU COMPETITION LAW}

The new enforcement system seems finally completed with the adoption of Directive 1. It is grounded on the foundations established with the Regulation: an allocation of competences among the Commission, NCAs and national Courts. In that, the two recent Directives adopt an approach that can be considered classical within EU Competition Law enforcement. Their novelties depend on the roles reserved to these controllers, the Commission assuming a central position, but not anymore the first; the NCAs and the national Courts strengthening their powers and consequently becoming important actors in the enforcement systems. 
After Member States implementations of Directive 1, time will be ripe to assess its efficacy and its good functioning. This is the current and fundamental challenge: on the one side, Member States need to cooperate sincerely in order to correctly implement and apply the Directives. Strong reforms might be needed, to the extent that the institution and the structure of NCAs are not anymore left to the full national competences. The current implementation period shall be useful for the discussions among Member States and within the ECN in order to grant the best national reforms to take place. Good practices detected in a comparative perspective might offer an example for those Member States whose current framework appears to depart from the principles established by Directive 1 with the goal of an efficient reform.

On the other side, the new EU Commission is empowered to check the application and the implementation of these rules. Although this Commission has not indicated Competition as its priority ${ }^{37}$, the continuity within the DG Competition leads us to suppose an unchanging state in the development of EU Competition Law. Since Directive 1 has been approved under the wishes of the same current Commissioner, controls on its correct implementation are easy to foresee.

Next years could be a test period: the legal framework is new and the practice must prove its effectiveness. The formally correct implementation of the Directives and the future establishment of a well-functioning system of public enforcement are only the grounds on which the enforcement of EU Competition Law can continue growing. The two systems, private and public, are not perfect and not well coordinated: still, the level playing field thus created shall be suitable to reduce the Commissions' workload without losing the quality of the enforcement itself and the protection of the victims. In that perspective, the combination of the two reforms might constitute a final point in legislative reforms and at the same time a good starting point for the best application of EU Competition Law.

\section{REFERENCES}

\section{BOOKS AND ARTICLES}

1. Calvo Caravaca, A.L.; Carrascosa González J., El Derecho internacional privado de la Unión Europea frente a las acciones por daños anticompetitivos, Cuadernos de derecho transnacional, vol. 10, no. 2, 2018, pp. 7-178

2. Chiriţoiu, GB.M., Convergence Within the European Competition Network: Legislative Harmonization and Enforcement Priorities, in: Almăşan, A.; Whelan P. (eds., The Consistent

37 Commission priorities for 2019-24 are available at: [https://ec.europa.eu/info/strategy/priorities-2019-2024_en] Accessed 15 April 2020 
Application of EU Competition Law. Substantive and Procedural Challenges, Cham, 2017, pp. $3 \mathrm{ff}$.

3. Frese, M.J., Case C-439/08, Vlaamse federatie van verenigingen van Brood-en Banketbakkers, Ijsbereiders en Chocoladebewerkers (VEBIC), Judgment of the European Court of Justice (Grand Chamber) of 7 December 2010, Common Market Law Review, vol. 48, no. 3, 2011, pp. 893-906

4. Jones, A.; Sufrin, B., EU Competition Law. Text, Cases and Materials, Oxford University Press, Oxford, 2016

5. Lianos, I.; David, P.; Nebbia, P., Damages Claims for the Infringment of EU Competition Law, Oxford University Press, Oxford, 2015

6. Malinauskaite J., Harmonisation of EU Competition law Enforcement, Springer, Cham, 2020

7. Marino, S.; Biel, Ł.; Bajčić, M.; Sosoni V. (eds.), Language and Law, Springer, Cham, 2018

8. Marino, S., Il rafforzamento dell'azione delle autorità nazionali garanti per la concorrenza: un nuovo impulso dall'unione europea, Rivista italiana di diritto pubblico comunitario, vol. 29, no. 3-4, 2019, pp. 537-557

9. Melloni, M., The European Competition Network (ECN) and its First 11 Years of Life: Balances and Challenges, in: Benacchio, G.A.; Carpagnano, M. (eds.), L'applicazione delle regole di concorrenza in Italia e nell'Unione europea, Napoli, 2015, pp. 48

10. Pace, L.F., La politica di decentramento del diritto antitrust CE come principio organizzatore del regolamento 1/2003: luci e ombre del nuovo regolamento di applicazione degli artt. 81 e $81 \mathrm{CE}$, Rivista Italiana di Diritto Pubblico Comunitario, vol. 14, no. 1, 2004, pp. 147-197

11. Pera, A.; Falce, V., The Modernisation of EC Competition Law and the Role of National Competition Authorities - Revolution or Evolution?, Diritto dell'Unione europea, vol. 8, no. 2-3, 2003, pp. 433-454

12. Petit, N., The Judgment of the European Court of Justice in VEBIC: Filling a Gap in Regulation 1/2003, Journal of European Competition Law \& Practice, vol. 2, no. 4, 2011, pp. 340-344

13. Reichelt, D., To what extent does the co-operation within the European Competition Network protect the right of undertakings?, Common Market Law Review, vol. 42, no. 3, 2005, pp. 745-782

14. Rusu, C.S., Case Comment: Workload Division after the Si.mobil and easyJet Rulings of the General Court, The Competition Law Review, vol. 11, no. 1, 2015, pp. 163-172

15. Tesauro, G., The evolution of European competition law and the Italian Autorità Garante della Concorrenza e del Mercato, in: H. Ullrich (ed.), The Evolution of European Competition Law: Whose Regulation, Which Competition?, Cheltenham, 2006, pp. 71-83

16. Wils, W.P.J., Private Enforcement of EU Antitrust Law and Its Relationship with Public Enforcement: Past, Present, Future, World Competition, vol. 40, no. 3, 2017, pp. 3-45

\section{COURT OF JUSTICE OF THE EUROPEAN UNION}

1. Case 127/73 BRT [1974] ECR 313

2. Case 792/79, Camera Care [1980] ECR 119

3. Cases 228 e 229/82, Ford [1982] ECR 2849 
4. Case T-24/90, Automec [1992] ECLI:EU:T:1992:97

5. Case C-453/99, Courage and Crehan [2001] ECR I-6297

6. Case T-184/01R, IMS Health Inc [2001] ECR II-3193

7. Case C-295/04, Manfredi [2006] ECR I-6619

8. Case C-429/07, Inspecteur van de Belastingdienst v X BV [2009] ECR I-04833

9. Case C-439/08, VEBIC, [2010] ECR I-12471

10. Case C-199/11, Otis [2012] ECLI:EU:C:2012:684

11. Case C-286/12, Commission v. Hungary [2012] ECLI:EU:C:2012:687

12. Case C-614/10, Commission v. Austria [2012] ECLI:EU:C:2012:631

13. Case C-288/12, Commission v. Hungary [2014] ECLI:EU:C:2014:237

14. CaseC-557/12, KoneAG and OthersvÖBB-InfrastrukturAG [2014]ECLI:EU:C:2014:1327

15. Case T-201/11, si.mobil [2014] ECLI:EU:T:2014:1096

16. Case C-353/13, CDC [2015] ECLI:EU:C:2015:335

17. Case C-27/17, flyLAL [2018] ECLI:EU:C:2018:533

18. Case C-64/16, Associação Sindical dos Juízes Portugueses [2018] ECLI:EU:C:2018:117

19. Case C-595/17, Apple [2018] ECLI:EU:C:2018:854

20. Case C-435/18, Otis [2019], ECLI:EU:C:2019:1069

21. Case C-451/18, Tibor-Trans [2019] ECLI:EU:C:2019:635

22. Case C-619/18, Commission v. Poland [2019] ECLI:EU:C:2019:531

\section{EU LAW}

1. Directive 95/46/EC of the European Parliament and of the Council of 24 October 1995 on the protection of individuals with regard to the processing of personal data and on the free movement of such data [1995] OJ L 281/31

2. Directive 2014/104/EU of the European Parliament and of the Council of 26 November 2014 on certain rules governing actions for damages under national law for infringements of the competition law provisions of the Member States and of the European Union [2014] OJ L 349/1

3. Council Regulation (EC) No 1/2003 of 16 December 2002 on the implementation of the rules on competition laid down in Articles 81 and 82 of the Treaty [2003] OJ L 1/1

4. Directive (EU) 2019/1 of the European Parliament and of the Council of 11 December 2018 to empower the competition authorities of the Member States to be more effective enforcers and to ensure the proper functioning of the internal market [2019] OJ L 11/3

\section{WEBSITE REFERENCES}

1. Commission priorities for 2019-24 are available at: [https://ec.europa.eu/info/strategy/priorities-2019-2024_en] Accessed 15 April 2020

2. EU Commission website: [https://ec.europa.eu/competition/antitrust/nca.html], Accessed 15 April 2020 